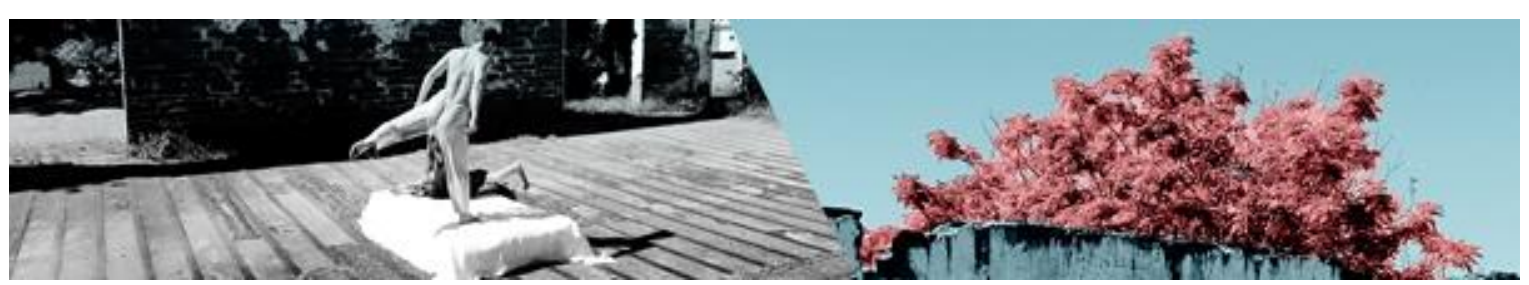

\title{
PRÁTICA DOCENTE E DANÇA DO VENTRE: UM ESTUDO SOBRE PROFESSORAS EM ATUAÇÃO NA CIDADE DE RIO GRANDE
}

\author{
Thaynara Garcia de Oliveira ${ }^{1}$ \\ Josiane Franken Corrêa ${ }^{2}$ \\ Helena Thofehrn Lessa ${ }^{3}$
}

\begin{abstract}
Resumo: Este trabalho tem como objetivo discutir a prática docente da Dança do Ventre, a partir de uma pesquisa realizada com professoras deste gênero de dança, na cidade de Rio Grande. É uma pesquisa qualitativa com uso de entrevista estruturada, que foi realizada com duas professoras. A discussão é feita a partir dos relatos das professoras e do cruzamento com fontes teóricas, trazendo um convite a refletir sobre as práticas docentes, especialmente em relação às histórias de vida e formação, à atuação profissional e às metodologias de ensino.
\end{abstract}

Palavras-chave: Dança do Ventre; Prática docente; Educação.

\section{TEACHING PRACTICE AND BELLY DANCE: A STUDY ABOUT TEACHERS WORKING IN THE CITY OF RIO GRANDE}

\begin{abstract}
This work aims to discuss the teaching practice of the Belly Dance from a research made with teachers of this dance style in the city of Rio Grande. It is a qualitative research with a structured interview, which was realized with two teachers. The discussion was made from the teachers' report and the crossing with theoretical sources, bringing an invitation to reflect on the teaching practices, especially in relation to life histories and formation, professional action and teaching methodologies.
\end{abstract}

Keywords: Belly Dance; Teaching practice; Education.

\footnotetext{
1 Graduada em Dança - Licenciatura pela Universidade Federal de Pelotas (2018). Seus primeiros estudos e experimentos em dança começaram em 2002, iniciando sua trajetória com a Dança do Ventre em 2006, tornando-se coreógrafa da Cia de Dança e Teatro de Corpo e Alma da cidade de Rio Grande/RS desde 2014.

2 Professora no Curso de Dança - Licenciatura, na Universidade Federal de Pelotas. Doutora (2018) e Mestre (2012 - Bolsista CAPES) em Artes Cênicas pela Universidade Federal do Rio Grande do Sul. Especialista em Corpo e Cultura: ensino e criação pela Universidade de Caxias do Sul (2010). Graduada em Dança - Licenciatura pela Universidade de Cruz Alta (2008). Desenvolve pesquisa em Artes Cênicas com foco em Ensino de Dança na Educação Básica e Práticas Pedagógicas em Dança.

${ }^{3}$ Graduada em Dança - Licenciatura pela Universidade Federal de Pelotas (2015) e em Fisioterapia pela Universidade Católica de Pelotas (2009). Doutora (2018) e Mestre (2014) em Educação Física pela Universidade Federal de Pelotas na área de concentração Movimento humano, educação e sociedade Linha de pesquisa Comportamento Motor. Foi professora substituta do Curso de Dança - Licenciatura da Universidade Federal de Pelotas de outubro de 2017 a janeiro de 2019. Atualmente é membro do Grupo de Pesquisa OMEGA - Observatório de Memória, Educação, Gênero e Arte.
}

OLIVEIRA, Thaynara Garcia de; CORRÊA, Josiane Franken; LESSA, Helena Thofehrn. Prática Docente e Dança do Ventre: um estudo sobre professoras em atuação na cidade de Rio Grande. Revista da FUNDARTE, Montenegro, p.73-89, ano 19, no 37, Janeiro/Março.

Disponível em: http://.seer.fundarte.rs.gov.br/index.php/RevistadaFundarte/index> 30 de março de 2019. 


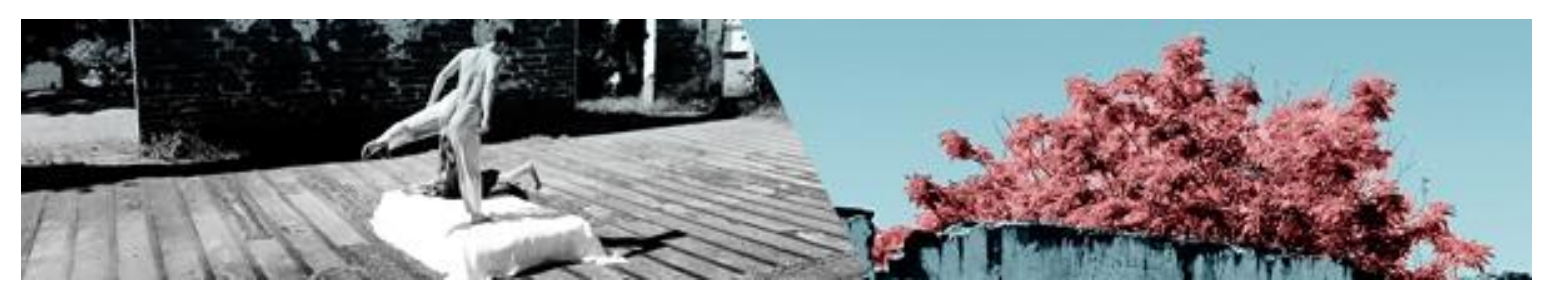

\section{Introdução}

O presente trabalho aborda a prática docente da Dança do Ventre nos espaços não formais de ensino e trata de um trecho revisado de uma pesquisa de conclusão de curso ${ }^{4}$, defendida pela autora no Curso de Dança - Licenciatura, da Universidade Federal de Pelotas em março de 2018.

A seleção do tema tem relação com o percurso da autora nos processos de ensino e aprendizagem da dança, especialmente da Dança do Ventre, gênero no qual a mesma passou da condição de estudante para a função de professora $^{5}$, trajeto percorrido por muitos profissionais desta arte. Desse modo, a escolha por desenvolver uma investigação acadêmica sobre o assunto é resultado da reflexão sobre a sua própria prática, o que incitou a busca de profissionais que também atuam como professoras $^{6}$ de Dança do Ventre no contexto delimitado.

Com a intenção de sinalizar os caminhos formativos, a atuação profissional e os fazeres metodológicos das professoras de Dança do Ventre da cidade de Rio Grande, realizou-se uma pesquisa exploratória de abordagem qualitativa (GERHARDT; SILVEIRA, 2009), na qual foram utilizadas entrevistas estruturadas que propiciaram a efetivação de um estudo de caso, contando com a colaboração de duas participantes.

As entrevistas ocorreram no segundo semestre de 2017, seguindo três eixos principais, sendo eles: 1) história de vida e formação; 2) atuação profissional; 3)

\footnotetext{
4 Trabalho intitulado Passando o "dum tac" adiante: um estudo sobre professoras de Dança do Ventre em atuação na cidade de Rio Grande/RS, orientado por Helena Thofehrn Lessa e apresentado em 01/03/2018.

${ }^{5}$ No trabalho, utiliza-se o termo "professor(a)" para se referir ao profissional que ministra aulas de dança, independente de formação acadêmica. Sabe-se que, legalmente, a atuação na docência é possibilitada pelo Curso de Licenciatura, porém, na área da Dança - que tem como característica a tradição (corp)oral, onde os conhecimentos são ensinados, muitas vezes, de geração a geração - professor(a) é tido como aquele(a) que ensina. Por isso, apesar de compreender a importância da formação no Ensino Superior, leva-se em consideração neste texto, o que é mais usual, até o momento, nas práticas de dança nos espaços não formais de ensino.

6 Optou-se por utilizar o termo "professora" porque as três autoras do trabalho e as professoras entrevistadas são mulheres.

OLIVEIRA, Thaynara Garcia de; CORRÊA, Josiane Franken; LESSA, Helena Thofehrn. Prática Docente e Dança do Ventre: um estudo sobre professoras em atuação na cidade de Rio Grande. Revista da FUNDARTE, Montenegro, p.73-89, ano 19, № 37, Janeiro/Março.

Disponível em: http://.seer.fundarte.rs.gov.br/index.php/RevistadaFundarte/index> 30 de março de 2019.
} 


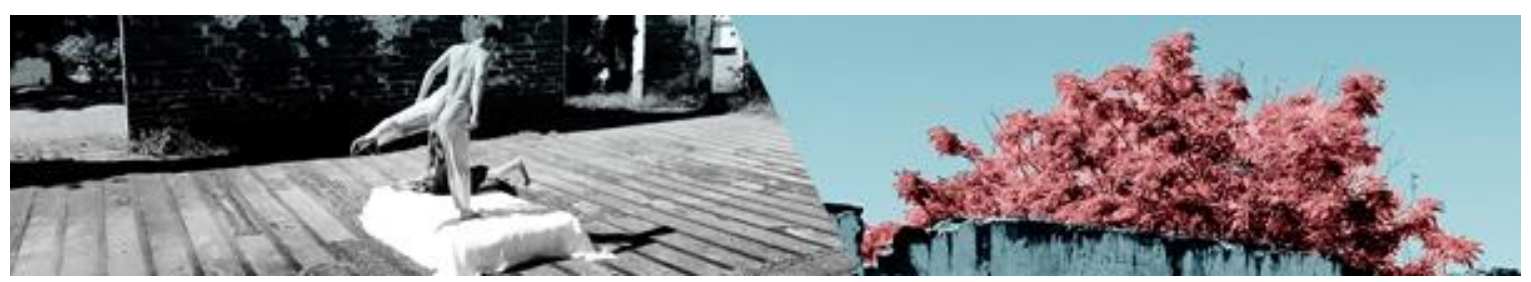

metodologia de ensino. Uma vez concluídas as entrevistas e suas transcrições, iniciouse a análise crítica do material, a qual foi realizada a partir do diagnóstico de uma matriz de análise, criada com base nas respostas obtidas nas entrevistas. Por meio desta matriz foi possível estabelecer um comparativo entre as respostas das professoras e, posteriormente, realizar um cruzamento com as fontes teóricas, percebendo aproximações e distanciamentos dentro de cada um dos três eixos em que estavam englobadas as questões da entrevista.

No fragmento aqui apresentado, é enfatizada a discussão sobre as práticas docentes com base na teoria de autores como Gianei (2006), Xavier (2006), Oliveira (2014) e Corrêa e Santos (2014), permeada às falas das participantes da pesquisa.

\section{Dança(s) do Ventre e Prática(s) Docente(s)}

No contexto brasileiro, a cultura árabe está presente no cotidiano por meio de influências em vários aspectos da vida, como, por exemplo: idioma, culinária, arquitetura, vestimentas, entre outros. Porém, suas influências vêm, antes ainda, de Portugal. Previamente aos registros da chegada de árabes no Brasil, algumas práticas foram disseminadas aqui pelos portugueses, acompanhados possivelmente de alguns árabes (PORTUGAL, 2011). Uma dessas práticas é a Dança do Ventre ${ }^{7}$. Enquanto manifestação artística, a Dança do Ventre foi amplamente disseminada para várias partes do mundo e, por isso, é preciso destacar que não existe uma única forma de praticá-la. Cada local em que a dança é praticada imprime características muito

\footnotetext{
7 A prática que aqui chamamos de Dança do Ventre pode ser intitulada de diversas maneiras, como: Raqs Sharki, Belly Dance, Dança do Oriente, Dança Árabe, Dança do Leste. Existem alguns pensamentos sobre a nomenclatura desta manifestação dançante. Um primeiro pensamento justifica usar o termo "Dança do Ventre" por acreditar que existem vários fatores que descaracterizam o termo "Dança Árabe", sendo um deles a influência egípcia; o outro viés diz que a nomenclatura correta, e mais utilizada nos países árabes é "Dança do Oriente" (KUSSUNOKI; AGUIAR, 2009). Neste trabalho, optamos por utilizar "Dança do Ventre" por acreditarmos ser o termo mais conhecido e utilizado desta dança no Brasil. OLIVEIRA, Thaynara Garcia de; CORRÊA, Josiane Franken; LESSA, Helena Thofehrn. Prática Docente e Dança do Ventre: um estudo sobre professoras em atuação na cidade de Rio Grande. Revista da FUNDARTE, Montenegro, p.73-89, ano 19, no 37, Janeiro/Março.

Disponível em: http://.seer.fundarte.rs.gov.br/index.php/RevistadaFundarte/index> 30 de março de 2019.
} 


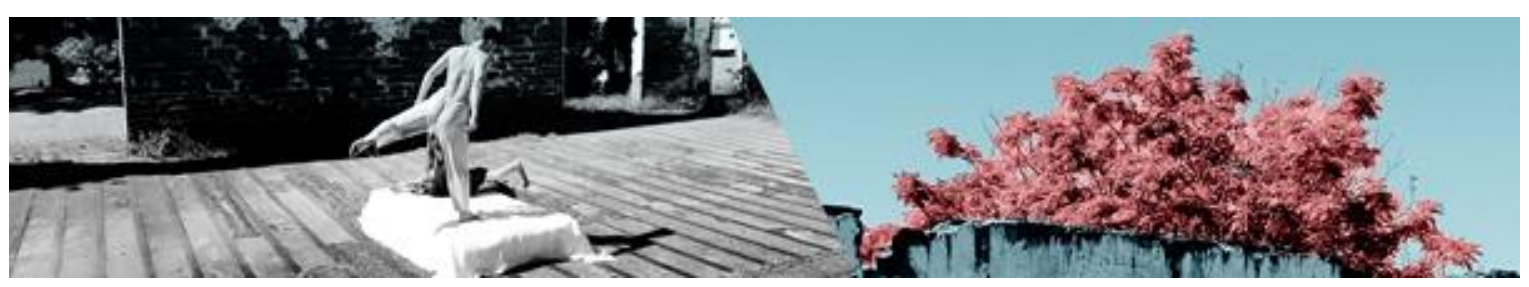

peculiares e contextuais, visto que existem várias formas de se dançar e, ainda, vários ritmos, instrumentos e indumentárias diferentes (XAVIER, 2006).

De modo similar, a prática docente de cada professora de dança é resultante de uma infinidade de influências formativas e contextuais, o que leva a crer na existência de muitas possibilidades para o ensino desta arte. De acordo com La Regina (1998 apud OLIVEIRA, 2011, p.17), "a Dança do Ventre é uma manifestação muito antiga que tem sido mantida, no Brasil, por meio do espaço não formal de dança". No entanto, conforme aponta Oliveira (2014), o ensino desse gênero de dança no país é recente:

O ensino da dança registrado no Brasil começou com uma única professora que chegou ao país com a imigração árabe, chamava-se Shahrazad Sharkey. Outras bailarinas se tornaram professoras por serem autodidatas. Constata-se que um recurso utilizado para o aprendizado dessa dança, naquela época, eram os vídeos cassetes lançados no Brasil. Assim, o primeiro vídeo didático sobre Dança do Ventre no Brasil, foi pela casa de chá Khan El Khalili, lançado em 1993, trouxe Lulu from Brazil como professora e bailarina. (OLIVEIRA, 2014, p.31).

A partir de sua experiência ao assistir bailarinas egípcias, libanesas e turcas, Xavier (2006) acredita que a Dança do Ventre, ao chegar ao Brasil, já tinha influências europeias e estadunidenses, já que as bailarinas adotavam posturas consideradas como "mais comportadas". A autora explica:

Comparando o que era ensinado no circuito brasileiro às danças que assisti posteriormente em vídeos de dançarinas egípcias, libanesas e turcas, percebi que os movimentos podem ser bruscos e exagerados e que a abertura das pernas dessas dançarinas muitas vezes ultrapassa a largura de seus quadris. Essas contradições podem ter relação com a tentativa de reduzir o conteúdo sexual da dança para torná-la mais palatável ao gosto do consumidor brasileiro. Contudo, aqui se apresenta uma questão bastante complexa, pois como se sabe as danças brasileiras de forma geral possuem conteúdos extremamente sexualizados e assim sendo, por que a necessidade de filtrar os conteúdos da dança do ventre? Eu acredito que os modelos de transmissão da dança do ventre no Brasil tenham sido adaptados de outras metodologias, em especial as europeias e estadunidenses, e que consequentemente a filtragem sexual tenha sido importada junto com os métodos. (XAVIER, 2006, p.52).

OLIVEIRA, Thaynara Garcia de; CORRÊA, Josiane Franken; LESSA, Helena Thofehrn. Prática Docente e Dança do Ventre: um estudo sobre professoras em atuação na cidade de Rio Grande. Revista da FUNDARTE, Montenegro, p.73-89, ano 19, no 37, Janeiro/Março.

Disponível em: http://.seer.fundarte.rs.gov.br/index.php/RevistadaFundarte/index> 30 de março de 2019. 


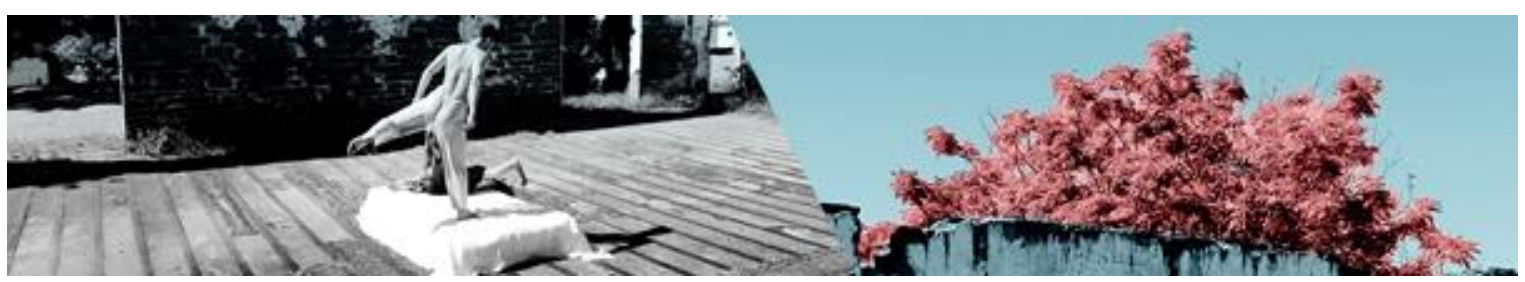

De forma geral, o ensino da Dança do Ventre segue uma metodologia fragmentada e progressiva, "dividindo" os movimentos e o corpo em várias partes. Geralmente se inicia com passos básicos e laterais, como as batidas de quadril (onde se movimenta o quadril para os lados); após, são realizados os primeiros passos com torções, como o twist (um lado do quadril vem para frente e o outro para trás, e viceversa), as tremidas, como o shimmy (em que se agita o quadril rapidamente para os lados), a fusão de movimentos e os deslocamentos em meia ponta. Após, normalmente são exigidas fluência, expressão e emoção para as performances. Contudo, muitas vezes não existe, nas aulas, o exercício da conexão e da fluência entre os passos (XAVIER, 2006). Oliveira (2014) afirma que existe uma forma tradicional de ensino para a Dança do Ventre que surge a partir da reprodução de movimentos. A autora critica essa forma de ensino, assim como a inexistência de professores com conhecimentos anátomo-fisiológicos na maior parte das academias de dança do Brasil.

Entende-se que não há um código que seja obrigatório a seguir e que as professoras de Dança do Ventre têm a liberdade de criar seus métodos particulares de ensino a partir dos passos básicos da Dança. Para isso, se faz importante buscar referências de apoio para fundamentar e gerar reflexões acerca da prática docente, para que esta não aconteça apenas de forma intuitiva. Assim como o primeiro vídeo cassete $^{8}$ lançado no Brasil com conteúdo de Dança do Ventre, outros dispositivos midiáticos começaram a dar visibilidade para esse gênero de dança, o que facilitou o acesso aos seus conteúdos e características. Como exemplo, pode-se citar novelas (como a intitulada "O Clone"9), portais (como a Central da Dança do Ventre ${ }^{10}$ ) e revistas (como a revista Shimmie ${ }^{11}$ ).

\footnotetext{
${ }^{8}$ Conforme referido anteriormente, foi lançado pela casa de chá Khan El Khalili em 1993.

${ }^{9}$ Novela brasileira produzida e exibida pela Rede Globo nos anos de 2001 e 2002. Em algumas cenas as atrizes dançavam junto de Bellydancers renomadas. A novela despertou atenção para a Dança do Ventre e instigou a busca pela prática dessa dança.

${ }_{10}$ Para acessar: http://www.centraldancadoventre.com.br/.

${ }_{11}$ Para acessar: http://www.lojashimmie.com.br/.

OLIVEIRA, Thaynara Garcia de; CORRÊA, Josiane Franken; LESSA, Helena Thofehrn. Prática Docente e Dança do Ventre: um estudo sobre professoras em atuação na cidade de Rio Grande. Revista da FUNDARTE, Montenegro, p.73-89, ano 19, no 37, Janeiro/Março.

Disponível em: http://.seer.fundarte.rs.gov.br/index.php/RevistadaFundarte/index> 30 de março de 2019.
} 


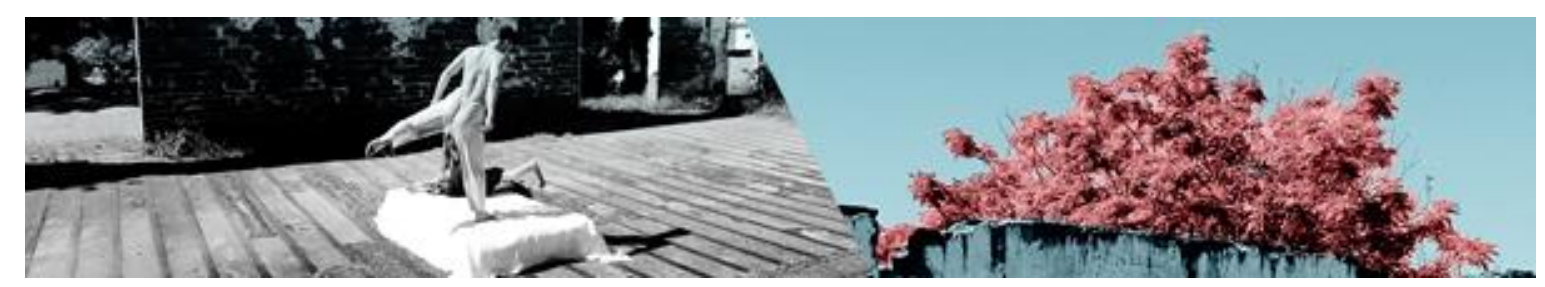

\section{Professoras de Dança do Ventre em Rio Grande: histórias de vida e formação, atuação profissional e metodologias de ensino}

Rio Grande é a cidade mais antiga do estado do Rio Grande do Sul e localiza-se no litoral, abrangendo a Praia do Cassino. Por sua localização geográfica, a parte econômica da cidade gira em torno do porto, visto que a construção de plataformas petrolíferas desenvolveu a economia, o comércio e a indústria, incentivando o estabelecimento de empresas nacionais e internacionais na cidade. Além do porto, a Universidade Federal do Rio Grande movimenta a cidade de modo intenso, desenvolvendo iniciativas artísticas, culturais e sociais para e com os moradores locais. Também a Escola de Belas Artes Heitor de Lemos, considerada importante marco cultural para a integração da população e para o desenvolvimento da dança na cidade, costuma realizar ações que potencializam o panorama artístico do contexto onde está inserida.

Para encontrar as professoras que trabalham com Dança do Ventre nos espaços não formais de ensino na referida cidade, inicialmente foi realizado um mapeamento por meio do site de busca Google. Num segundo momento, buscou-se por espaços com anúncios de aulas de Dança do Ventre na cidade que poderiam não ter registro na internet. No total foram identificados dez espaços, mas apenas cinco estavam ofertando aulas de Dança do Ventre naquele momento. A partir da busca por esses espaços, foi possível conseguir o contato de cinco professoras de Dança do Ventre, sendo que duas delas aceitaram o convite para participar do presente estudo. Por uma questão ética e de escolha metodológica, as identidades das professoras serão mantidas em sigilo no decorrer do texto, tratando-as por professoras "A" e "B".

Em relação às suas trajetórias na dança, a professora "A" teve início a partir do acesso a recursos midiáticos e apreciação de apresentações que nutriam seu desejo de dançar, para posteriormente iniciar seus estudos práticos em Dança do Ventre. Ela relata que costumava assistir apresentações artísticas que aconteciam na cidade em OLIVEIRA, Thaynara Garcia de; CORRÊA, Josiane Franken; LESSA, Helena Thofehrn. Prática Docente e Dança do Ventre: um estudo sobre professoras em atuação na cidade de Rio Grande. Revista da FUNDARTE, Montenegro, p.73-89, ano 19, no 37, Janeiro/Março.

Disponível em: http://.seer.fundarte.rs.gov.br/index.php/RevistadaFundarte/index> 30 de março de 2019. 


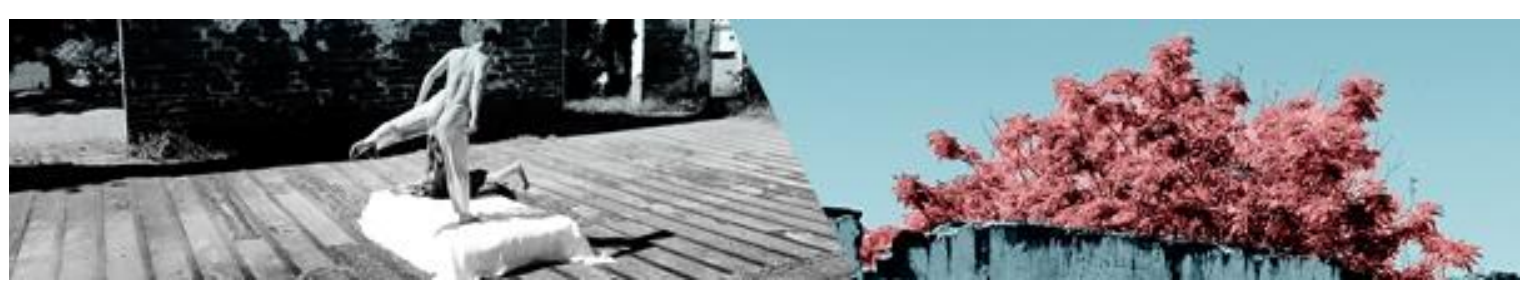

que morava: "Todo show que tinha, eu ia. E eu cuidava o quadril delas, cuidava os pés delas, e quando eu chegava em casa eu tentava reproduzir o máximo que eu podia. E aí quando eu consegui fazer um arranjo nas minhas contas eu comecei a fazer aula." (Informação verbal Professora A).

A professora "B" iniciou seus estudos em Dança do Ventre aos 16 anos, sendo, então, sua primeira experiência com dança. No entanto, sua atuação docente iniciou mais tardiamente, aos 30 anos de idade. Diferentemente, no estudo de Pérez et al. (2012), que buscou identificar a formação de professoras de Dança do Ventre na cidade de Caxias do Sul, os resultados apontaram que $25 \%$ das professoras iniciaram suas atividades profissionais aos 16 anos, faixa etária apontada pela professora "B" como ponto de partida para seus estudos.

É interessante destacar que a professora "B" considera ter começado tardiamente sua aproximação com a dança e gostaria de ter um entendimento maior sobre o Balé Clássico, o qual considera "básico" para o aprimoramento técnico de qualquer modalidade de dança. Roble e Lima (2013) problematizam essa relação do Balé Clássico com a Dança do Ventre:

Notando a insipiência das metodologias de ensino em Dança do Ventre, muitos dos sujeitos depositam no Balé Clássico uma confiança de que o mesmo possa incrementar o aprendizado. Com frequência ele foi apresentado ou como sugestão de condicionamento para a Dança do Ventre ou como necessidade técnica para a mesma, visto que ele supostamente propicia força muscular, postura adequada e melhora da habilidade de giros. (ROBLE; LIMA, 2013, p.1042).

De fato, no início do século XX a Dança do Ventre se aproximou do Balé Clássico. Gianei (2006) expõe que a Dança do Ventre não possuía grande variação espacial, movimentos de torso e braços nos países orientais, mas a partir do contato com a cultura ocidental, a dança incorporou passos com giros e deslocamentos. Nessa época, também foram introduzidos a posição dos pés na meia ponta e o uso de sapatos

OLIVEIRA, Thaynara Garcia de; CORRÊA, Josiane Franken; LESSA, Helena Thofehrn. Prática Docente e Dança do Ventre: um estudo sobre professoras em atuação na cidade de Rio Grande. Revista da FUNDARTE, Montenegro, p.73-89, ano 19, № 37, Janeiro/Março.

Disponível em: http://.seer.fundarte.rs.gov.br/index.php/RevistadaFundarte/index> 30 de março de 2019. 


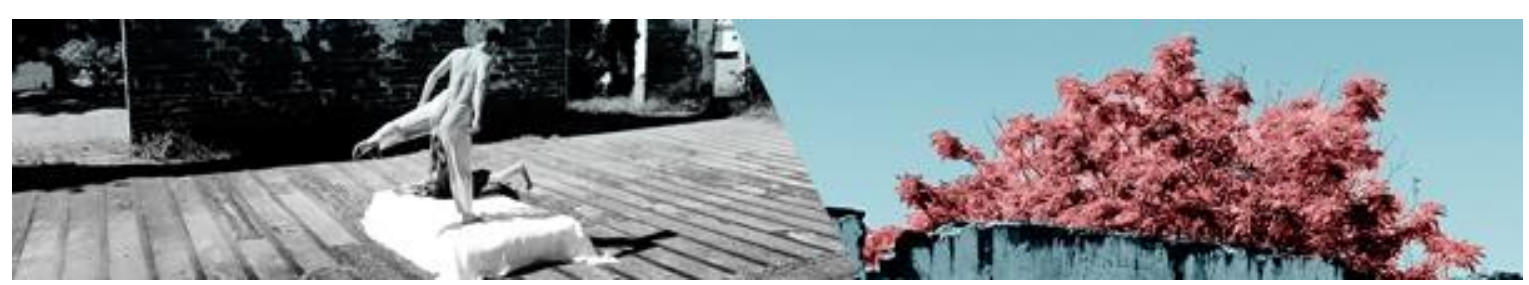

de salto por algumas bailarinas, como Sâmia Gamal ${ }^{12}$, conforme ressaltado por Mahaila (2016). Além disso, cabe destacar o material didático desenvolvido pela bailarina Suheil ${ }^{13}$, o qual utiliza a relação de posições e movimentos do Balé Clássico com a Dança do Ventre como possibilidade pedagógica e reflexão sobre a consciência corporal.

A experiência com o Balé Clássico pode agregar na realização de determinados movimentos, mas acredita-se que cada gênero de dança, dentro de sua especificidade, pode abranger o tipo de trabalho que acredita ser necessário para a construção do corpo cênico, o que vai depender das experiências e metodologias de cada professora, bem como das singularidades e interesses de cada turma que podem trazer demandas diversas. Concordando com Corrêa, Silva e Santos (2017), acredita-se que, independentemente do gênero de dança adotado pelas professoras em sala de aula, é prudente, por parte do docente, buscar aquilo que acredita ser uma prática coerente com o seu papel no espaço de ensino onde está inserido e, também, procurar compreender o porquê das suas escolhas.

Nesse sentido, entende-se como de extrema relevância a conexão da prática docente ao tempo presente, ou seja, a postura pedagógica deve estar relacionada ao conjunto de atitudes expressado no discurso e na prática artística da contemporaneidade, refletindo-se em um ensino caracterizado pelo respeito à diversidade de corpos, pela democracia na dança e pelo incentivo à autonomia (CORRÊA; SANTOS, 2014; CORRÊA; SILVA; SANTOS, 2017).

Sobre as motivações para se tornarem professoras de dança, a professora "A" relata que identificou uma dificuldade de compreensão dos movimentos por ela mesma e por suas colegas devido à metodologia de ensino de sua professora. A partir desse

12 Sâmia Gamal era bailarina no Cassino Ópera por volta de 1940 e dançou na Companhia de Danças Badia Massabn, ambas situadas no Egito.

${ }^{13}$ Suheil é bailarina profissional com mais de 20 anos de experiência na Dança do Ventre. Para saber mais: http://www.suheil.com.br/.

OLIVEIRA, Thaynara Garcia de; CORRÊA, Josiane Franken; LESSA, Helena Thofehrn. Prática Docente e Dança do Ventre: um estudo sobre professoras em atuação na cidade de Rio Grande. Revista da FUNDARTE, Montenegro, p.73-89, ano 19, № 37, Janeiro/Março.

Disponível em: http://.seer.fundarte.rs.gov.br/index.php/RevistadaFundarte/index> 30 de março de 2019. 


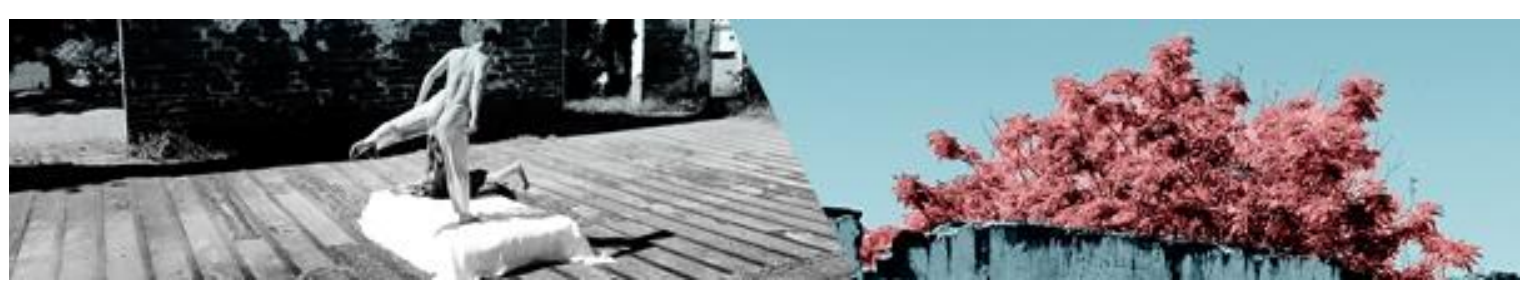

pensamento, ela começou a procurar outras formas de explicar os movimentos e descobriu seu gosto pela docência nesse processo:

(...) eu perguntei quando que a gente ia começar a ondular o ventre e a minha professora me falou "é um movimento do camelo, só que tu vai parando a movimentação do camelo e vai mantendo a contração no ventre, mas é isso". E tipo assim, é isso! Tu não te tocou que é isso? E ali eu pensei "cara, não pode ser só essa forma de ensinar uma ondulação" e eu queria saber mais, eu queria mais, eu queria mais informação... e eu percebia que as informações que eu queria eu não recebia da forma como eu gostaria e algumas alunas às vezes tinham dificuldade (...) e eu percebi que eu conseguia explicar a dificuldade delas de uma forma que a professora não explicava, e aquilo me agradava, eu gostava de explicar, gostava de explicar como que ela [a colega/ as colegas] não tava conseguindo fazer o passo e por quê (...), foi assim que eu percebi que aquele amor de ensinar tava se mantendo em mim. (Informação verbal Professora A).

Já a professora "B" menciona que ser professora de Dança do Ventre não é a sua ocupação principal e que possui um emprego que ocupa 40 horas da sua semana. Começou sua trajetória na docência a partir do interesse de suas amigas em fazer aulas de Dança do Ventre, e enxergou nessa oportunidade uma possibilidade de dançar, estudar e se atualizar na área da dança, encontrando motivação em suas alunas:

[...] o que me motiva também são as alunas, né, que eu acho que... que eu acho que enxergar, assim, a importância que a dança adquire na vida delas, é uma coisa que me coloca muito pra frente assim, tipo... ver as pessoas se empoderando, tendo uma outra relação com o corpo, tendo uma outra relação com a sua autoestima, eu acho que... pra mim é bastante importante, né... oportunizar a dança para outras pessoas me motiva bastante. (Informação verbal Professora B).

Em relação à formação continuada, a professora "A" relatou a realização de alguns cursos em Campinas no início de sua formação. A professora "B" cita alguns cursos fora da cidade, um trabalho autodidata - que pode ser relacionado com a professora "A" no início de seu aprendizado - e suas pesquisas pela internet. Estas buscas por uma amplitude de suas práticas na Dança do Ventre entre as duas professoras entrevistadas podem ser chamadas de buscas pelos saberes da

OLIVEIRA, Thaynara Garcia de; CORRÊA, Josiane Franken; LESSA, Helena Thofehrn. Prática Docente e Dança do Ventre: um estudo sobre professoras em atuação na cidade de Rio Grande. Revista da FUNDARTE, Montenegro, p.73-89, ano 19, № 37, Janeiro/Março.

Disponível em: http://.seer.fundarte.rs.gov.br/index.php/RevistadaFundarte/index> 30 de março de 2019. 


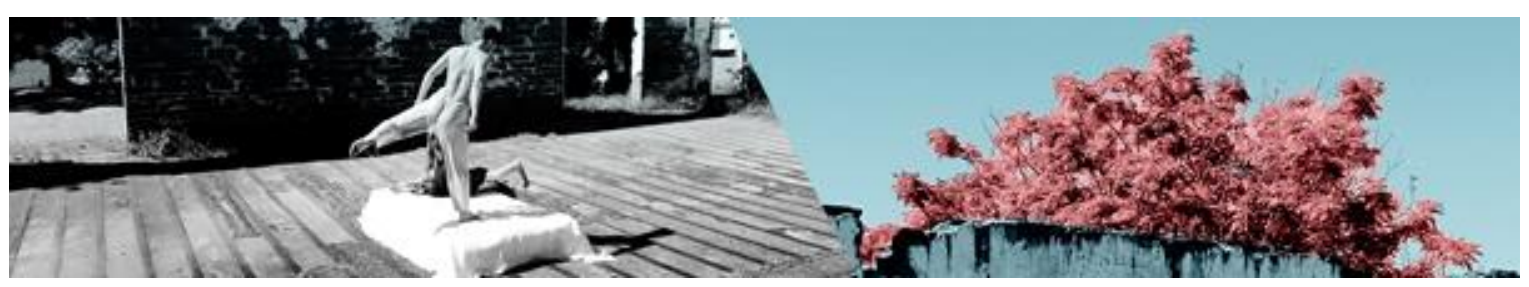

experiência. Andrade e Godoy (2017) escrevem sobre a importância desse tipo de saber para a formação dos professores de arte. Segundo as autoras:

Na formação de professores em arte, esses saberes podem se complementar, pois os estudantes-artistas que se tornarão professores, na maior parte das vezes, passaram não só por experiências artísticas definidoras da linguagem escolhida, como também pelos bancos escolares. A experiência, nesse caso, fortalece a formação do artista e do professor. (ANDRADE; GODOY, 2017, p.118).

Jesus (2015) complementa a ideia exposta ao discorrer sobre formação:

Pensando na formação de professores, podemos refletir que um sujeito experimentado não é aquele que se acomoda em sua zona de conforto, mas sim aquele que se lança no mundo porque sabe que o seu saber é provisório. Compreende-se, assim, que o educador nessa perspectiva seria aquele que vê o aprender como um processo contínuo, algo que se dá ao longo de uma vida. (JESUS, 2015, p.5).

Nesse sentido, a atuação profissional também é formadora, na perspectiva de que, ao enfrentar situações específicas da prática docente, boa parte das professoras revisam suas crenças em relação ao seu fazer profissional e se colocam em um estado autocrítico. Diante desse estado, compreende-se que a busca por novas informações é uma maneira de ampliar os horizontes. Independente da formação superior em dança, "do professor não se espera uma atitude de passividade em relação ao saber dança, mas sim que ele faça da sua docência uma pesquisa contínua" (CORRÊA; SANTOS, 2014, p. 522).

Para que uma formação continuada exista não precisa necessariamente se estar numa sala de aula - independente do espaço de ensino - ou lendo artigos, teses, livros e outras publicações. Há uma outra alternativa de formação, que é a apreciação de espetáculos, mostras, festivais e/ou performances.

Esse professor que incorpora a arte poderá compartilhar esse universo em seus aspectos mais amplos. O professor que vibra ao descobrir um novo livro, um novo artista, um novo museu; que se entusiasma ao descobrir outra faceta de seu artista predileto (...) sem dúvida terá muito mais a dialogar e a ensinar e

OLIVEIRA, Thaynara Garcia de; CORRÊA, Josiane Franken; LESSA, Helena Thofehrn. Prática Docente e Dança do Ventre: um estudo sobre professoras em atuação na cidade de Rio Grande. Revista da FUNDARTE, Montenegro, p.73-89, ano 19, no 37, Janeiro/Março.

Disponível em: http://.seer.fundarte.rs.gov.br/index.php/RevistadaFundarte/index> 30 de março de 2019. 


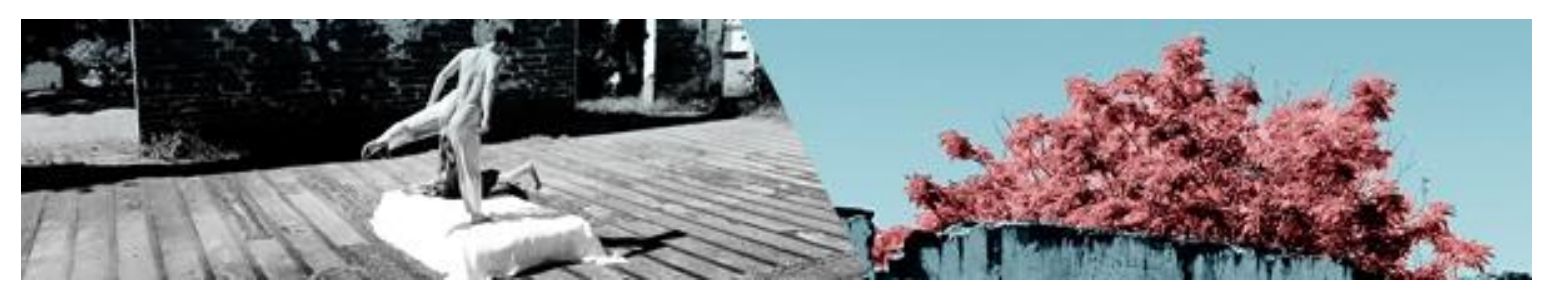

estará certamente construindo conhecimento significativo com os estudantes. (MARQUES; BRAZIL, 2014, p.54).

A partir do exposto, sugere-se a apreciação em dança também como possibilidade de formação do ser docente. No entanto, cabe dizer que, no entendimento das autoras do presente estudo, uma formação continuada que se pretenda de forma integral ocupa a pesquisa, a prática e a apreciação. Acredita-se que cada docente faz suas escolhas formativas, mas tais escolhas afetam diretamente os fazeres metodológicos das professoras.

Sobre esses fazeres metodológicos, Gianei (2006) aponta a construção de um método pessoal como um dos possíveis caminhos para o ensino da Dança do Ventre. Com forte herança na tradição, em que os conhecimentos sobre a dança eram passados de geração em geração - assim como outras danças, especialmente as populares e folclóricas - a prática docente da Dança do Ventre normalmente envolve a reprodução dos movimentos aprendidos de forma intuitiva sem a consciência do percurso do movimento. Partindo dessa realidade e da vontade de mudança, o desenvolvimento de um método particular aparece como uma possibilidade de ampliar o ensino da Dança do Ventre.

Nesse sentido, a professora "B" relatou que costuma desenvolver um planejamento de acordo com o nível de cada turma. Já a professora "A" possui uma tabela progressiva com passos a serem ensinados em um determinado nível para as alunas, mas relata que essa tabela é flexível ao andamento de cada turma. É interessante refletir que as professoras, apesar de terem um planejamento fixo - seja por turma, seja um planejamento geral - se preocupam com o "como" as alunas compreendem as aulas, o tempo de aprendizado que cada aluna e cada turma possui. Ambas demonstraram preocupação em adaptar o planejamento para cada situação, atitude docente que se aproxima da colocação de Marques e Brazil (2014): "planejar serve para podermos ver adiante, sonhar, desenhar, crer, projetar, vislumbrar caminhos

OLIVEIRA, Thaynara Garcia de; CORRÊA, Josiane Franken; LESSA, Helena Thofehrn. Prática Docente e Dança do Ventre: um estudo sobre professoras em atuação na cidade de Rio Grande. Revista da FUNDARTE, Montenegro, p.73-89, ano 19, no 37, Janeiro/Março.

Disponível em: http://.seer.fundarte.rs.gov.br/index.php/RevistadaFundarte/index> 30 de março de 2019. 


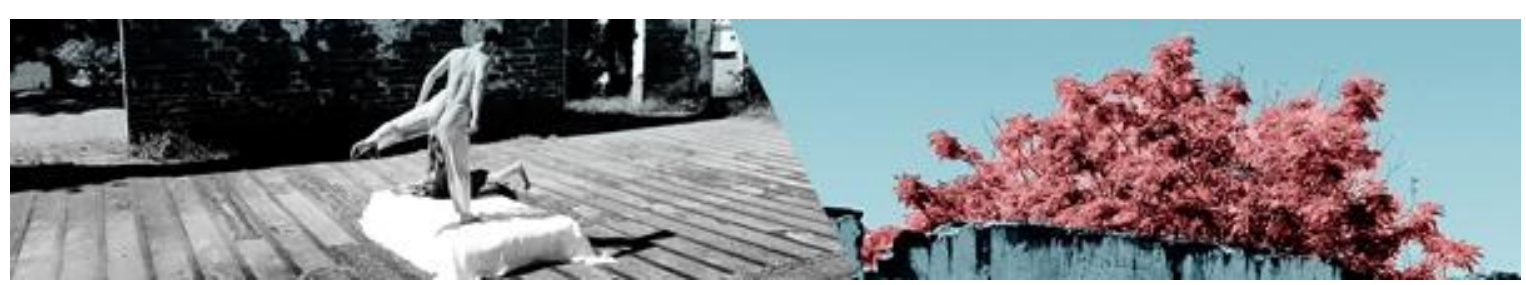

de ação e de transformação com a contribuição da Arte nas vidas dos estudantes" (MARQUES; BRAZIL, 2014, p.106).

Outra informação interessante de ser destacada neste trabalho é o relato da professora "B". Segundo ela, seu maior tempo como aluna em aulas de Dança do Ventre foi com a professora "A". Talvez, por esse motivo, suas formas de planejamento de aula sejam parecidas. Ao perguntar sobre como o andamento da aula costuma acontecer, a professora "A" diz iniciar por um "esqueletinho" e vai progredindo o movimento até a concretização do passo em si. Ela também relata que faz um registro escrito do que cada turma aprendeu. Já a professora "B" começa com alongamento e aquecimento, seguindo para um trabalho de condicionamento físico e, dependendo do nível de aprendizado da turma, ensina passos ou sequências de movimentos. Ao fim, realiza um relaxamento que se destine principalmente aos quadris e aos membros inferiores.

É importante colocar aqui a importância de ter uma preparação corporal anterior ao início dos primeiros movimentos. A professora "A" começa com a repetição de movimentos de forma progressiva e a professora "B" destaca um momento da aula apenas para alongamento e condicionamento para executar determinados passos:

Eu inicio a aula sempre com um alongamento e aquecimento, também costumo fazer um trabalho de condicionamento né, de força, a gente faz abdominal, prancha, agachamento, varia um pouquinho... Então os primeiros 20, 25 minutos da aula são voltados a isso, geralmente a minha turma... As aulas são de uma hora, hã... No meio da aula... Depende do nível da turma, mas geralmente, passos, sequência ou coreografia, e no final da aula a gente faz um... Um relaxamento e um alongamentinho também voltado pra... pra área do quadril, dos membros inferiores sobretudo. (Informação verbal Professora B).

Sobre as possíveis estratégias pessoais utilizadas pelas professoras para tornar o ensino mais efetivo, a professora "B" não soube responder e a professora "A" diz utilizar uma abordagem lúdica, forma que encontrou de fazer as alunas se sentirem à vontade:

OLIVEIRA, Thaynara Garcia de; CORRÊA, Josiane Franken; LESSA, Helena Thofehrn. Prática Docente e Dança do Ventre: um estudo sobre professoras em atuação na cidade de Rio Grande. Revista da FUNDARTE, Montenegro, p.73-89, ano 19, no 37, Janeiro/Março.

Disponível em: http://.seer.fundarte.rs.gov.br/index.php/RevistadaFundarte/index> 30 de março de 2019. 


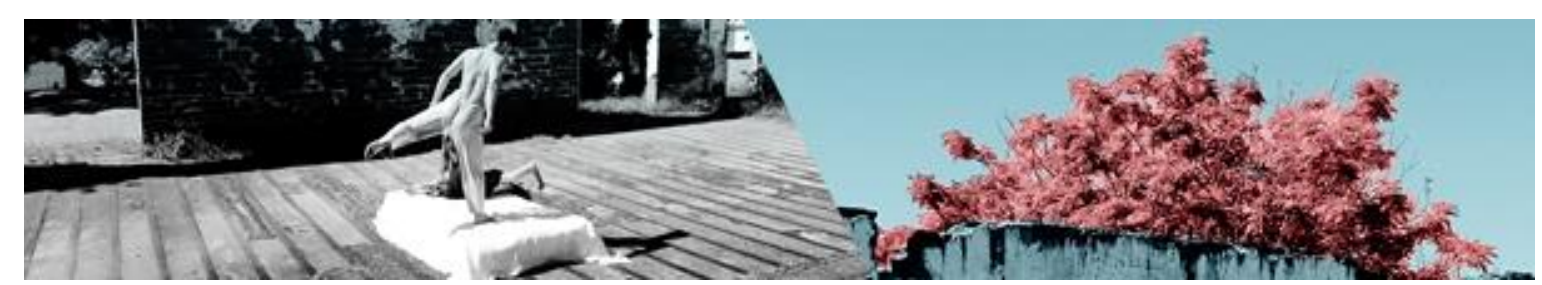

Eu levo elas muito na brincadeira. Porque num geral elas tão sempre muito nervosas, tensas pra aprender. $\mathrm{E}$ acham que nunca vão conseguir dançar, eu levo isso numa forma um pouco mais... como eu te expliquei, pedacinho por pedacinho até elas entenderem que elas são capazes de fazer, e sempre na brincadeira. (Informação verbal Professora A).

Por envolver uma trajetória ampla, algumas vezes as professoras não percebem as estratégias que utilizam durante uma aula e outra ou entre uma turma e outra. Às vezes, são ações naturalizadas que já estão impregnadas no seu fazer e não são vistas pelas professoras como uma forma pessoal de criar um ambiente de aprendizado mais efetivo para suas alunas. Porém, isso faz parte do caminho particular traçado por cada professora e indica seu perfil docente.

Para essa discussão, podemos trazer o conceito de currículo oculto de Imbernón (2011), usado para se referir aos modelos docentes que a professora interiorizou enquanto aluna. Ou seja, o modo de planejar a atividade docente, as estratégias e hábitos que percebemos nos nossos professores estão implícitos no nosso modo de ensinar. Assim, a elaboração da metodologia particular terá reflexos do currículo oculto mesclado com os traços pessoais de cada docente:

Uma elaboração metodológica não deixa de ser um quebra-cabeça armado com peças de diferentes vivências em um enquadramento pessoal, cuja coerência decorre das experiências e memórias de cada um. Encontramos, assim, a singularidade de cada professor-pesquisador no modo como os seus procedimentos são concretizados a partir de suas ações e convicções, como num processo criativo em que se pode criar sua aula dançada por meio de inspirações, desejos e insights. (MILLER, 2012, p.148).

Por esse motivo, a reflexão e a ampliação da prática docente envolvem também a conscientização acerca dos currículos ocultos que atravessam a trajetória formativa:

É relevante que façamos, continuamente, a análise da nossa prática, na tentativa de compreender os "currículos ocultos" que nos fazem professores. Esta compreensão possibilita o posicionamento e a reflexão crítica perante as metodologias de ensino, o que nos faz acolher ou descartar modelos docentes. Mesmo assim, não teremos controle do professor que somos ou queremos ser, pois as fronteiras da experiência e como a exteriorizamos não são precisas, o

OLIVEIRA, Thaynara Garcia de; CORRÊA, Josiane Franken; LESSA, Helena Thofehrn. Prática Docente e Dança do Ventre: um estudo sobre professoras em atuação na cidade de Rio Grande. Revista da FUNDARTE, Montenegro, p.73-89, ano 19, № 37, Janeiro/Março.

Disponível em: http://.seer.fundarte.rs.gov.br/index.php/RevistadaFundarte/index> 30 de março de 2019. 


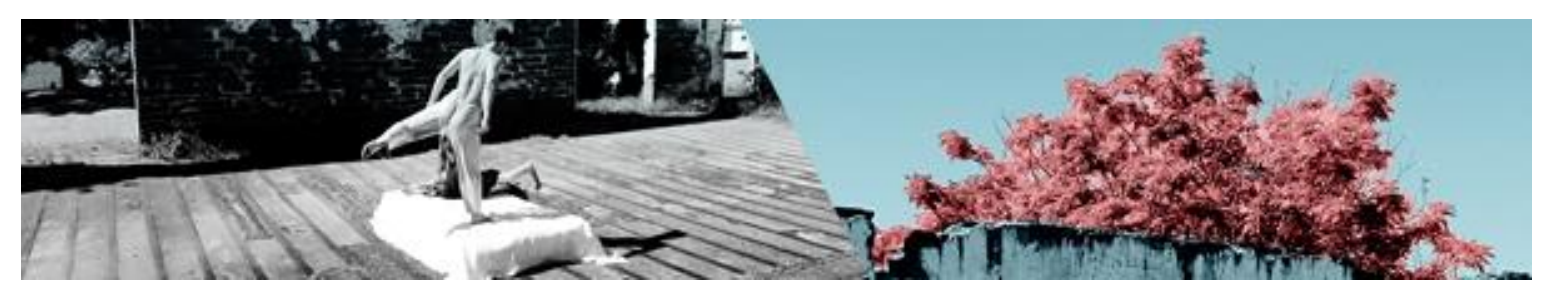

que transforma a reflexão e a melhora da própria prática numa tentativa e jamais numa certeza absoluta. (FRANKEN, 2013, p.6).

Analisar a prática também envolve o desenvolvimento da sensibilidade enquanto docente que se atenta para o contexto e se coloca no lugar dos(as) alunos(as), trabalhando de forma que "[...] haja cuidado e respeito para com a diversidade cultural e corporal, para com as possibilidades de aprendizado de acordo com os níveis de desenvolvimento e para com o processo e refinamento da autonomia do aluno" (CORRÊA; SANTOS, 2014, p.522).

Ao abordar a autonomia, é possível traçar um cruzamento com o relato da professora "A", a qual costuma explicar "pedacinho por pedacinho até elas entenderem que elas são capazes de fazer", algo que, segundo ela, é uma forma de instigar a autoaceitação e a superação de suas alunas. Nesse sentido, autonomia nem sempre é dar liberdade total aos(às) alunos(as), mas deixá-los(las) experimentar e compreender o caminho do movimento no corpo, é refletir sobre o que está se aprendendo durante as aulas e o que aquilo modifica ou acrescenta em suas vidas. Seguindo as pistas de Miller (2012):

No século $X X I$, faz-se cada vez mais urgente compreender a técnica como um conjunto de vários procedimentos de investigação e aplicação de um conteúdo. Não se trata de apontar o que é melhor ou pior, certo ou errado - ou qualquer outra dicotomia -, mas de eleger, de modo consciente, processos de atuação e transformação para a construção de um corpo cênico que não reduz a pessoa a um instrumento a ser lapidado. Ao contrário, remete-a ao soma, ao eu indivíduo que trabalha com a autonomia de um pesquisador em prontidão. (MILLER, 2012, p.27).

Faz parte do planejamento docente conseguir direcionar as ações, ao mesmo tempo em que se permite aos alunos experimentarem formas de executar determinado movimento e perceberem caminhos possíveis. Segundo Marques e Brazil (2014), "se a dança for trabalhada como linguagem e construção de arte, o corpo e o movimento serão vividos de outras formas pelos estudantes" (MARQUES; BRAZIL, 2014, p.38).

OLIVEIRA, Thaynara Garcia de; CORRÊA, Josiane Franken; LESSA, Helena Thofehrn. Prática Docente e Dança do Ventre: um estudo sobre professoras em atuação na cidade de Rio Grande. Revista da FUNDARTE, Montenegro, p.73-89, ano 19, № 37, Janeiro/Março.

Disponível em: http://.seer.fundarte.rs.gov.br/index.php/RevistadaFundarte/index> 30 de março de 2019. 


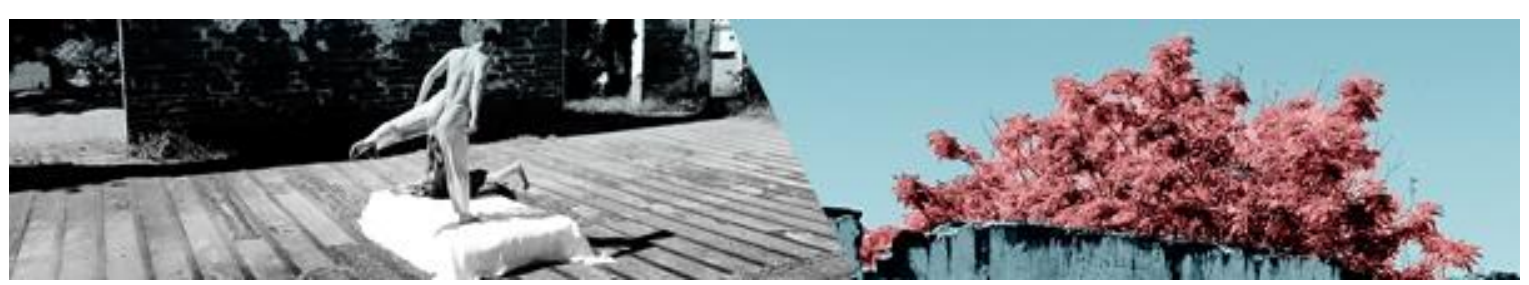

\section{Considerações}

A pesquisa realizada despertou reflexões sobre os fazeres docentes. Acredita-se na possibilidade de potencializar as professoras locais a partir de suas próprias histórias. Cada docente possui sua história peculiar e sua forma de chegar ao lugar da docência, e evidenciar as histórias de professoras locais significa ampliar a visibilidade tanto delas quanto da Dança do Ventre no Brasil; assim como evidenciar cidades ou regiões é uma forma de apontar como a Dança do Ventre se organiza naquele contexto.

Entende-se que esta pesquisa ampliou a percepção acerca das professoras de Dança do Ventre da cidade, como suas experiências influenciam suas formas de pensar e criar as aulas. Além disso, faz repensar as práticas, assim como encontrar pontos parecidos e diferentes entre as formas de pensar as aulas. Para os(as) leitores(as), professores(as) ou futuros(as) professores(as) de dança, é uma possibilidade de conhecer como a Dança do Ventre está disposta na cidade de Rio Grande, e também uma maneira de refletir sobre as práticas docentes das duas professoras entrevistadas. Isso incide na reflexão sobre a própria prática, possibilitando a criação - ou recriação - da forma como pensa em trabalhar como professor(a) de dança.

\section{Referências:}

ANDRADE, Carolina Romano de; GODOY, Kathya Maria Ayres de. A formação do professor para a dança: reflexões sobre um curso de formação continuada. Art Research Journal, v.4, n.1, p.114-140, 2017.

CORRÊA, Josiane Franken; SANTOS, Vera Lúcia Bertoni dos. Dança na Educação Básica: apropriações de práticas contemporâneas no ensino de dança. Revista Brasileira de Estudos da Presença, v.4, n.3, p.509-526, 2014.

OLIVEIRA, Thaynara Garcia de; CORRÊA, Josiane Franken; LESSA, Helena Thofehrn. Prática Docente e Dança do Ventre: um estudo sobre professoras em atuação na cidade de Rio Grande. Revista da FUNDARTE, Montenegro, p.73-89, ano 19, № 37, Janeiro/Março.

Disponível em: http://.seer.fundarte.rs.gov.br/index.php/RevistadaFundarte/index> 30 de março de 2019. 


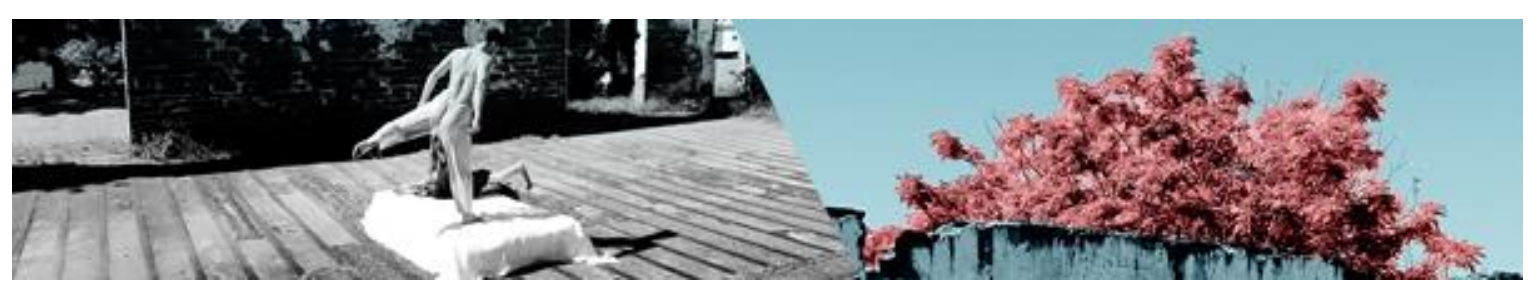

CORRÊA, Josiane Franken; SILVA, lassanã Martins da; SANTOS, Vera Lúcia Bertoni dos. Concepções pedagógicas no ensino de dança: apontamentos. Revista da Fundarte, v.17, n.34, p.31-44, 2017.

FRANKEN, Josiane. Reflexões e Reflexos do Sistema Laban/Bartenieff na Prática Docente em Dança. Cena em Movimento, n.3, 2013.

GERHARDT, Tatiana Engel; SILVEIRA, Denise Tolfo. Métodos de pesquisa. Porto Alegre: Editora da UFRGS, 2009. Disponível em: <http://www.ufrgs.br/cursopgdr/downloadsSerie/derad005.pdf>. Acesso em 8 fev. 2017.

IMBERNÓN, Francisco. Formação docente e profissional: formar-se para a mudança e a incerteza. 9. ed. São Paulo: Cortez, 2011.

JESUS, Caroline Kummer de. Olhares para a docência em dança: processos formativos e experiência. Revista de Educação, Ciência e Cultura, v.20, n.1, p.117-125, 2015.

KUSSUNOKI, Sandra Aparecida Queiroz; AGUIAR, Carmen Maria. Aspectos históricos da dança do ventre e sua prática no Brasil. Motriz, v.15, n.3, p.708-712, 2009.

MAHAILA, Brysa. Os pilares da profissionalização em dança do ventre: história e folclore, volume 1. São Paulo: Kaleidoscópio de ideias, 2016.

MARQUES, Isabel; BRAZIL, Fábio. Arte em questões. São Paulo, Cortez, 2014.

MILLER, Jussara. Qual é o corpo que dança? : dança e educação somática para adultos e crianças. São Paulo: Summus, 2012.

OLIVEIRA, Eugênia Squeff de. Dança do Ventre: técnica, expressão e significados. Uma etnografia nas Escolas de dança em Pelotas/RS. 2011. 117 f. Dissertação (Mestrado em Ciências Sociais) - Instituto de Sociologia e Política, Universidade de Pelotas, Pelotas. Disponível em: <http://guaiaca.ufpel.edu.br/handle/123456789/1555>. Acesso em 28 ago. 2016.

OLIVEIRA, Ana Carolina Moreira de. A relação ensino e dança: diálogos entre Laban e a dança do ventre. História e Culturas, v.2, n.3, p.26-39, 2014.

OLIVEIRA, Thaynara Garcia de; CORRÊA, Josiane Franken; LESSA, Helena Thofehrn. Prática Docente e Dança do Ventre: um estudo sobre professoras em atuação na cidade de Rio Grande. Revista da FUNDARTE, Montenegro, p.73-89, ano 19, № 37, Janeiro/Março.

Disponível em: http://.seer.fundarte.rs.gov.br/index.php/RevistadaFundarte/index> 30 de março de 2019. 


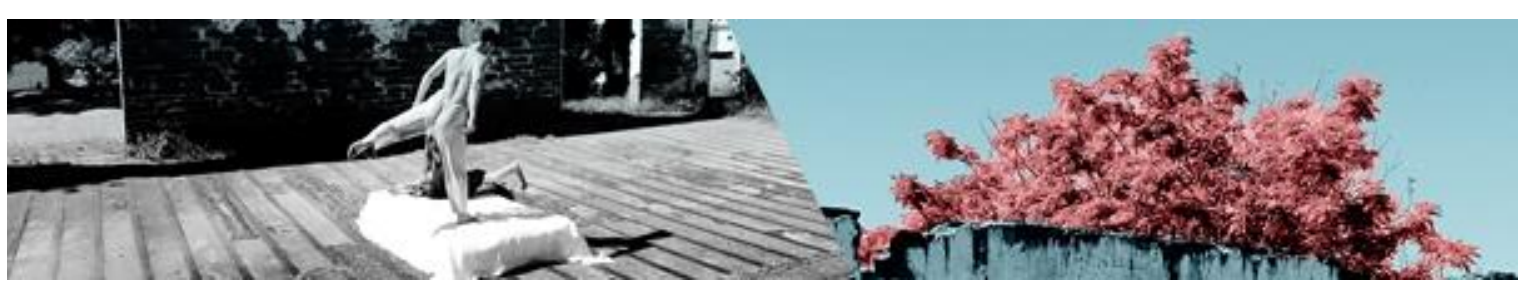

PEREZ, Vanessa Sanders Curi; HAAS, Aline Nogueira; GONÇALVES, Ângela Cristina Bugs; LIMA, Isadora de Souza Maia. Formação de professoras de dança do ventre. Revista da Fundarte, v.1, p.29-32, 2012.

PORTUGAL, Ana Raquel. O legado árabe no Brasil. Ibérica - Revista interdisciplinar de Estudos Ibéricos e Ibero-Americanos, v.5, n.16, p.4-21, 2011.

GIANEI, Beatris Cristina Possato. Arabesco: imaginários e violências nas narrativas da dança do Oriente. 2006. 210 f. Dissertação (Mestrado em Educação) - Universidade Estadual de Campinas, Campinas. Disponível em: <http://repositorio.unicamp.br/jspui/bitstream/REPOSIP/253776/1/Gianei_BeatrisCristina Possato_M.pdf>. Acesso em 21 mar 2018.

ROBLE, Odilon José; LIMA, Karen Adrie de. Dança do ventre: evoluções e proposições de uma década. Pensar a prática, v.16, n.4, p.956-1270, 2013.

XAVIER, Cíntia Nepomuceno. Do oito ao Infinito: por uma dança sem ventre, performática, híbrida, impertinente. 2006. 130 f. Dissertação (Mestrado em Artes) Universidade de Brasília, Brasília. Disponível em: $<$ http://repositorio.unb.br/handle/10482/5669?mode=full>. Acesso em: 16 abr. 2016.

OLIVEIRA, Thaynara Garcia de; CORRÊA, Josiane Franken; LESSA, Helena Thofehrn. Prática Docente e Dança do Ventre: um estudo sobre professoras em atuação na cidade de Rio Grande. Revista da FUNDARTE, Montenegro, p.73-89, ano 19, № 37, Janeiro/Março.

Disponível em: http://.seer.fundarte.rs.gov.br/index.php/RevistadaFundarte/index> 30 de março de 2019. 